\title{
Project Based Learning Model in Improving The Ability and Trust
}

\author{
Desi Fitria $^{1}$, Melly Susanti ${ }^{2}$, Mardhiyah Dwi Ilhami ${ }^{3}$ \\ ${ }^{12}$ Muhammadiyah Bengkulu University, ${ }^{3}$ Dehasen Bengkulu University \\ * Corresponding author: \\ Email: melisusantisanti017@gmail.com
}

\begin{abstract}
.
This research is focused on providing experience to teachers specifically in developing teaching materials by using project based learning. The purpose of this study is to assist teachers in improving the effectiveness and creativity of students in developing student confidence.

Research and development continued with quasi-experiment in collaboration with class-room teachers. Stages of research to be carried out, namely: (1) preparation, (2) develop-ment, (3) experimental phase, (4) evaluation. The subjects of this study were teachers and students from SMKN 01, SMKN 02, SMKN 03 in Bengkulu City. Furthermore, at the implementation stage a collaborative experiment was carried out where the implementation of learning collaborates with the teacher and was designed online. The results of this study with the learning of the project model can develop students' confi-dence and can improve students' self-creativity.
\end{abstract}

Keywords: Teaching Materials, Project based Learning, Self Confidence

\section{INTRODUCTION}

Efforts to improve student mastery of econom-ics at the school level really need to be improved. This can provide sufficient provisions in life and the field of work so as to solve problems relating to the economy. One of the efforts is the implementation of the 2013 curriculum which emphasizes students to think with the aim of making Indonesian individuals who are productive, creative, innovative, and affective through strengthening attitudes.

Accounting lessons are very important in equipping students in real life. The importance of accounting lessons requires all parties to make improvements, especially those directly related to learning activities. In addition, accounting subjects listed in accountings are used as a benchmark for graduation in high school. Furthermore, in the selection of an accounting college one of the subjects that determine the graduation prerequisites for the social and humanities choice. This shows that accounting is important for students to master. However, the reality shows that one of the student learning outcomes in accounting subjects needs to be improved. Data from the Ministry of Education and Culture (2019) shows that the average score of the Computer-Based National Examination (UNBK) at the Social Sciences Department 
level in the 2018/2019 academic year is 46.86 from the $0-100$ scale. This shows that the sub-jects tested were accounting that were classified as low.

The results of the initial survey in one of the high schools in the city of Bengkulu through an in-terview with one of the high school teachers ob-tained several findings. These findings include: (1) students were not accustomed to finding their own concepts, (2) students still have difficulty in convey-ing the results of group discussions, (3) students were not accustomed to using real cases in learning, (4) learning materials were not widely found eco-nomics that can encourage students' thinking abilities and student skills. One effort that can be done to improve the quality of learning by designing learning so as to facilitate students in developing their abilities and confidence in learning. These efforts using learning media in the form of teaching materials specifically were designed to develop students' abili-ties in understanding the concept of the material. However, the reality in schools shows that learning tools are rarely found that can be used by teachers directly for learning, especially in developing stu-dents' abilities and confidence.

In this view, Project Based Learning (PBL) is one of the recommended methods to use. PBL refers to a method that allows "students to design, plan, and implement extended projects that produce outputs that are publicly exhibited such as products, publications, or presentations" (Patton, 2012: 13). Through PBL, students engage in communication aimed at completing authentic activities (project-work), so that they have the opportunity to use language in a relatively natural context (Haines, 1989, as cited in Fragoulis, 2009) and participate in meaningful activities which requires the use of native languages (Fragoulis, 2009). The successful implementation of PBL has been reported by Gaer (1998) who taught speaking skills to the Southeast Asian refugee population who were already in their early grade ESOL (Economy for Speakers of Other Languages) classes. Their speaking skills were enhanced through PBL economic students. This study seeks to find out whether PBL can improve students 'speaking skills or not, what aspects of speech are improved, and what speaking activities are used to improve students' speaking skills. The scope of this study reveals the use of PBL in developing student confidence and improving student creativity during and after the Covid-19 pandemic. During and after the pandemic, students used the online method of communicating with teachers. The transition period from face to face method changes using online, this is not easily accepted by students. Especially in remote areas in Bengkulu province, where access to the internet still faces constraints on weak networks or signals.

The researchers of this study analyzed how the project-based learning model could be accepted and could improve students' creativity in applying learning theory both during and after the Covid-19 pandemic.

\section{METHODS}

The research design used was in the form of quasi-experimental research. The purpose of this study is to test the practicality of the learning model given by the teacher, namely the project based learning model, with this PBL model the teachers 
can improve the quality of learning of senior high school students in Accounting and Financial department. In this case, the researchers got involved directly into the classroom from diagnosing difficulties / obstacles encountered in the learning process then formulating an action plan, implementing learning, monitoring the action process, reflecting and refining the action process, and evaluating the results of the actions or effectiveness of the model. This research activity were carried out through the following stages:

a. Preparation (conducting material and curriculum studies)

b. Development, At this stage two main activities were carried out, namely: (1) Validation, (2) practicality, (3) Field Trial Activities

c. Stage of Collaborative Experiments Conduct learning trials using teaching materials that were designed in the ways of face-to-face and online.

\section{Data Collecting Technique}

Data collection techniques were divided into two stages, namely development research carried out by observation and distributing validity and practicality evaluation sheets. Validity data collection was done online by contacting experts, namely economics lecturers. While the practicalism test was conducted with a small group conducted by visiting students and teachers of high schools in Bengkulu city while applying the health protocol. In the experimental stage the data collection was done by giving tests to students after the treatment was given. In addition, observations were made to observe the implementation of the learning stages in accordance with the project based learning model.

\section{Data Analysis}

Development Research

1. Validity Analysis

The validity estimation used in this study applies the item validity index proposed by Aiken with the following formula:

$\mathrm{V}=\frac{\mathrm{\Sigma} \mathrm{e}}{\mathrm{n}(\mathrm{c}-1 \mathrm{q})}$, with $\mathrm{g}=\mathrm{r}-\mathrm{I}_{0}$

Information:

$V=$ validity index

$\mathbf{s}=$ the score set for each rater minus the lowest score

$\mathrm{n}=$ rater choice category score

$\mathrm{I}_{0}=$ lowest score in the scoring category

$\mathrm{c}=$ the number of categories rater can choose from

$\mathrm{n}=$ the number of raters (Retnawati, 2014: 3)

Practical Analysis

The trial data that had been obtained was then converted into qualitative data on a five scale. The conversion on a scale of five was adapted from Widoyoko (2009) as in the following table:

Table 1. Criteria for Practicality of Learning Devices

\begin{tabular}{|l|l|}
\hline Score Interval & Category \\
\hline $\mathrm{X} \geqslant \mathrm{X}_{1}+\mathbf{1 , 6 \mathrm { s } \mathbf { b } _ { \mathrm { i } }}$ & Very practical \\
\hline
\end{tabular}

http://ijstm.inarah.co.id 


\begin{tabular}{|c|c|}
\hline $\mathrm{X}_{0}+0,6 \mathrm{~s} \mathrm{~h}_{1} \leqslant \mathrm{X} \leqslant \mathrm{X}+1,6 \mathrm{~s}$ & Practical \\
\hline $\mathrm{X}_{1}-0,6 \mathrm{~s} \mathrm{~b}_{1}<\mathrm{X}<\mathrm{X}+0,6 \mathrm{~s}$ & Moderate \\
\hline 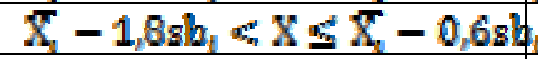 & Less practical \\
\hline $\mathrm{X} \leq \mathrm{X}_{1}-1,8 \mathrm{~s} \mathrm{~b}_{1}$ & Not practical \\
\hline
\end{tabular}

Collaborative Experiment Research

Average Learning Outcomes

$X=\frac{\Sigma X}{N}$

Information : $\mathbf{X}=$ Students' Average Score

$\mathbf{\Sigma} \mathrm{X}=$ Total number of students' score

$\mathrm{N}=$ Number of students (Sudjana, 2009)

Hypothesis test

In the collaborative experiment stage, data analysis was performed to test the following hypotheses.

$$
\begin{aligned}
& H_{0}: \mu_{1}=\mu_{2} \\
& H_{1}: \mu_{1} \neq \mu_{2} \\
& \mu_{1}=\text { average learning outcomes with teaching using teaching materials } \\
& \mu_{2}=\text { average learning outcomes without teaching materials }
\end{aligned}
$$

The statistical hypothesis was tested using the t-test with formulas:

$$
\mathrm{t}=\frac{\bar{x}_{1}-\bar{x}_{2}}{\sqrt{s^{2} g a b\left\{\left(\frac{1}{n_{1}}\right)+\left(\frac{1}{n_{2}}\right)\right\}}}
$$

With $\mathrm{s}_{2} \mathrm{gab}=\frac{\left(n_{1}-1\right) s^{2}{ }_{1}+\left(n_{2}-1\right) s^{2}{ }_{1}}{n_{1}+n_{2}-2}$

\section{RESULT AND DISCUSSION}

3.1 Development Research Results

a. Expert Trial Result Data

Project based learning based learning materials that have been prepared were assessed by experts who aim to see the quality of the product in terms of content. The trial results show that teaching materials in the form of Student Activity Sheets (LKS) met valid criteria. The validity test results of teaching materials are as follows. 
Table 2. Teaching Material Validation Results

\begin{tabular}{|c|l|c|l|}
\hline No & \multicolumn{1}{|c|}{ Rated Aspect } & Aiken Index & Criteria \\
\hline 1 & Formulation and Purpose & 0,74 & Valid \\
\hline 2 & Conformity of Content and Material & 0,71 & Valid \\
\hline 3 & Learning Activities & 0,72 & Valid \\
\hline 4 & Language accuracy & 0,70 & Valid \\
\hline 5 & Learning Resources & 0,69 & Valid \\
\hline 6 & Penerapan PjBL & 0,73 & Valid \\
\hline
\end{tabular}

The results of the validator's assessment of the teaching material above show a valid category. This shows that in theory economic teaching materials based on project based learning models met valid criteria.

\subsection{Results of Collaborative Experiments}

Description of student learning outcomes

The schools selected in the implementation of collaborative experiments consisted of three schools, namely: (1) SMK Negeri 1 Bengkulu City, (2) SMK Negeri 2 Bengkulu City, and (3) SMA Negeri 3 Bengkulu City. In each school one class was chosen as the experimental class, namely class $\mathrm{X}$ majoring in social studies. Description of student learning outcomes after being given learning by using projectbased learning based learning materials is shown in the following table:

Table 3. Student Learning Outcomes Data

\begin{tabular}{|l|c|c|c|}
\hline Names of School & $\begin{array}{c}\text { Number of } \\
\text { Students }\end{array}$ & $\begin{array}{c}\text { Average } \\
\text { Scores }\end{array}$ & $\begin{array}{c}\text { Percentage } \\
(\%)\end{array}$ \\
\hline SMAN 1 Kota Bengkulu & 31 & 74.97 & 83,90 \\
\hline SMAN 3 Kota Bengkulu & 33 & 75,54 & 84.85 \\
\hline SMAN 6 Kota Bengkulu & 36 & 74.80 & 80.56 \\
\hline
\end{tabular}

Based on the table above, it can be seen that the percentage of students mastery learning classically that reaches KKM is more than $65 \%$. In addition, the average value of the two trial classes has reached the KKM value. This shows that the learning tools developed have met the effective criteria.

\section{CONCLUSION}

After applying the model of learning i.e. project based learning, the result is the ability to learn and the confidence of students of SMKN 1, SMKN 2 and SMKN 3 Bengkulu City can be improved. This can be seen in the results of the $t$-test, where the results of $t$ count are greater than $t$ table. The $t$-test table shows the students' knowledge after the use of teaching materials with $t$-count $>t$-table and significant $<0.005$. The research by developing teaching materials using project based learning could also improve students' independence in the process of accepting economic subject matterials. The students were even more creative in developing innovation in the field of science being studied. 
So the results of this study are accepting $\mathrm{HO}$ and rejecting Ha, meaning that after the project based learning model was applied, there was an improvement in knowledge and confidence of students of SMKN 1, SMKN 2 and SMKN 3 Bengkulu City, this study is in line with the research of Susanti et al.,(2020) which shows that the learning model with the project based learning model is effective in terms of the conceptual knowledge aspects.

This research has a weakness that is the lack of tools used in the development of teaching materials such as student worksheets (LKS), internet networks in schools were still very low connected, along with props used in developing project-based learning models to improve the abilities of high school students in Bengkulu city.

\section{ACKNOWLEDGMENTS}

With the completion of this research, I would like to thank RESTIDIKTI, Muhammadiyah Bengkulu University, and my team who have helped a lot until the completion of all the outcomes in this research.

\section{REFERENCES}

[1] Allwright, R. L. (1981). What do we want teaching materials for? ELT Journal, 36(1), 5-18. https://doi.org/10.1093/elt/36.1.5

[2] Astrini, K. S., Suwendra, I. W., \& Suwarna, I. K. (2014). Pengaruh CAR, LDR dan Bank Size Terhadap NPL pada Lembaga Perbankan yang Terdaftar di Bursa Efek Indonesia. E-Journal Bisma Universitas Pendidikan Ganesha Jurusan Manajemen, 2(1), 1-8.

[3] Barab, S., Zuiker, S., Warren, S., Hickey, D. A. N., Ingram-goble, A., Kwon, E., Kouper, I., \& Herring, S. C. (2007). Curriculum: Relating Formalisms and Contexts. Science Education, 91, 750-782. https://doi.org/10.1002/sce

[4] Darch, C., \& Carnine, D. (1986). Teaching Content Area Material to Learning Disabled Students. Exceptional Children, 53(3), 240-246. https://doi.org/10.1177/001440298605300307

[5] Darini Bilqis Maulany. (2013). THE USE OF PROJECT-BASED LEARNING IN IMPROVING THE STUDENTS' SPEAKING SKILL (A Classroom Action Research at One of Primary Schools in Bandung). Journal of English and Education, 1(June), 52-58.

[6] Ellis, R. (1997). The empirical evaluation of language teaching materials. ELT Journal, 51(1), 36-42. https://doi.org/10.1093/elt/51.1.36

[7] Grant, M. M. (2002). Getting a grip on project-based learning: Theory, cases and recommendations. In Meridian (Vol. $5, \quad$ Issue 1 ). https://www.scopus.com/inward/record.uri?partnerID=HzOxMe3b\&scp=3042553 637\&origin=inward

[8] Harwood, N. (2005). What do we want EAP teaching materials for? Journal of English for Academic Purposes, 4(2), 149-161. https://doi.org/10.1016/j.jeap.2004.07.008

[9] Schwarz, C. V., Gunckel, K. L., Smith, E. L., Covitt, B. A., Bae, M., Enfield, M., \& Tsurusaki, B. K. (2008). Helping elementary preservice teachers learn to use curriculum materials for effective science teaching. Science Education, 92(2), 
345-377. https://doi.org/10.1002/sce.20243

[10] Shih, W. C., Tseng, S. S., \& Yang, C. T. (2008). Wiki-based rapid prototyping for teaching-material design in e-Learning grids. Computers and Education, 51(3), $1037-1057$.

[11] Susanti, M., Herfianti, M., Damarsiwi, E. P. M., Perdim, F. E., \& Joniswan. (2020). Project-based learning model to improve students' ability. International Journal of Psychosocial Rehabilitation, 24(2).

[12] Tomlinson, B. (2012). Materials development for language learning and teaching. In Language Teaching (Vol. 45, Issue 2, pp. 143-179). https://doi.org/10.1017/S0261444811000528

[13] Tsiplakides, I., \& Fragoulis, I. (2009). Project-based learning in the teaching of English as a foreign language in Greek primary schools: from theory to practice. English Language Teaching, 2(3), 113-119. https://doi.org/10.5539/elt.v2n3p113

[14] Williams, P. (2002). The Learning Web. Active Learning in Higher Education, 3(1), 40-53. https://doi.org/10.1177/1469787402003001004

[15] Yuliana, C. (2020). Pengembang Teknologi Pembelajaran. https://lpmplampung.kemdikbud.go.id/detailpost/project-based-learning-modelpembelajaran-bermakna-di-masa-pandemi-covid-19 